\title{
MANAJEMEN PEMBELAJARAN \\ DALAM MENINGKATKAN EFEKTIVITAS PROSES BELAJAR MENGAJAR DI MASA PANDEMI COVID-19
}

\author{
Ahmad Munir Saifulloh \\ Institut Agama Islam Syarifuddin Lumajang, Indonesia \\ Email: saifullohahmadmunir@gmail.com \\ Mohammad Darwis \\ Institut Agama Islam Syarifuddin Lumajang, Indonesia \\ Email: mohammad.darwis70@gmail.com
}

\begin{abstract}
Abstrak
Menajemen pembelajaran sangat penting kedudukannya dalam rangka meningkatkan efektivitas proses belajar mengajar, apalagi di masa darurat penyebaran Corona Virus Disease-19 (COVID-19) seperti yang kita alami saat ini. Berbagai usaha dilakukan untuk meningkatkan kualitas pendidikan dengan tetap mempertimbangkan protokol kesehatan sesuai dengan SKB 4 Mentri. Berbagai hambatan, kesulitan, dan keterbatasan dihadapi dalam proses belajar mengajar, mulai dari faktor peserta didik, keluarga peserta didik, maupun sarana dan prasarana yang kurang representatif, namun kementrian pendidikan dan kebudayaan (kemendikbud) tetap menginstruksikan seluruh pendidik di semua jenjang pendidikan agar dapat menciptakan pembelajaran yang menyenangkan dari rumah baik siswa maupun mahasiswa. Oleh karena itu, peran guru sangat dibutuhkan dalam memanage atau mengelola pembelajaran mulai dari perencanaan (planning), pengorganisasian (organizing), pelaksanaan (actuating) dan evaluasi (evaluating) dalam rangka meningkatkan efektivitas proses belajar mengajar di masa pandemi COVID-19 saat ini, baik implementasi pembelajaran jarak jauh dalam jaringan (daring) maupun luar jaringan (luring).
\end{abstract}

Kata kunci: Manajemen Pembelajaran, Efektivitas Pembelajaran, COVID-19.

\section{Pendahuluan}

Pembelajaran menjadi suatu hal yang sangat penting dalam kegiatan pendidikan. Memudahkan pembelajaran bagi peserta didik merupakan tugas mulia bagi seorang guru. Untuk itu guru tidak hanya dituntut untuk membuat suasana pembelajaran menjadi nyaman dan menarik, akan tetapi guru juga harus memahami dan menguasai ilmu tentang manajemen pembelajaran baik di dalam maupun di luar kelas. Guru harus mampu memilih dan menerapkan metode pembelajaran yang 
sesuai dengan kompleksivitas materi dan karakter masing-masing peserta didik. Sehingga metode dan pendekatan yang diterapkan benar-benar sesuai dengan perkembangan diri peserta didik karena peserta didik merupakan subjek dan bukan sebagai objek dalam kegaiatan belajar mengajar.

Oleh karena itu, guru harus mampu menggunakan metode dan pendekatan serta penggunaan sarana dan prasarana yang tepat agar proses belajar mengajar menjadi menarik dan menyenangkan. Memberikan ruang yang seluas-luasnya bagi peserta didik untuk berkrativitas dan terlibat aktif sepanjang proses pembelajaran. Hingga ranak kognitif, afekti dan psikomotor peserta didik dapat tumbuh berkembang secara maksimal dan bersamaan tanpa mengalami pengkerdilan.

Dalam interaksi pembelajaran sangat dipengaruhi oleh beberapa komponen yaitu: peserta didik, guru, kepala sekolah, kurikulum, fasilitas sekolah (perpustakaan), miliu dan beberapa fasilitas lain yang dibutuhkan dalam proses pembelajaran sehingga akan menunjang kualitas pembelajaran ${ }^{1}$ Dengan demikian, kegiatan pembelajaran dapat membawa perubahan bagi peserta didik, baik perubahan pengetahan, perilaku, maupun keterampilan. Dengan perubahan-perubahan ini, tentunya peserta didik akan terlatih dalam menyelesaikan permasalahan hidup dan bisa beradaptasi dengan lingkungannya. ${ }^{2}$

\section{PEMBAHASAN}

\section{Manajemen Pembelajaran}

Istilah manajemen mengandung multi makna, tergantung pada latar belakang pendidikan dan pengalaman orang yang menafsirkannya. Istilah manajemen sering disandingkan dan dibandingkan dengan istilah

\footnotetext{
1 A. Marjuni, Hamzah Harun, Penggunaan Multimedia Online dalam Pembelajaran, Jurnal IDAARAH, VOL. III, NO. 2, DESEMBER 2019, (diakses 07 Juli 2020), 195.

2 Jojo Warjo dkk, Implikasi Gaya Berpikir dan Interaksi Sosial Siswa pada Pembelajaran Model Kooperatif Berbasis Media Informasi dan Komunikasi Terhadap Prestasi Belajar Siswa, EDUBIOLOGICA, Vol. 6, No. 1, Juni 2018, (Diakses 07 Juli 2020), 16.
} 
administrasI. Terdapat tiga pandangan berbeda; pertama, dimaknai lebih umum dari pada manajemen (manajemen merupakan core dari administrasi); kedua, melihat manajemen lebih umum dari pada administrasi dan ketiga, pandangan yang menggangap bahwa manajemen sama dengan administrasi. Berdasarkan fungsinya istilah manajemen dan administrasi mempunyai fungsi yang sama. Oleh sebab itu, perbedaan maupun persamaan keduanya tidak urgen dan konsisten.

Dalam memahami istilah manajemen, pendekatan yang diaplikasikan adalah berdasarkan pengalaman seorang pimpinan. Manajemen sebagai suatu sistem merupakan suatu proses untuk mencapai target organisasi secara maksimal dan komprehensif. Untuk meraih target organisasi dilaksanakan dengan pengelolaan fungsi-fungsi perencanaan (planning), pengorganisasian (organizing), penyusunan personalia atau kepegawaian (staffing), pengarahan dan kepemimpinan (learding), dan pengawasan (controlling). ${ }^{3}$

Manajemen merupakan proses yang khusus dengan target untuk mencapai suatu tujuan secara maksimal dengan memaksimalkan semua fasilatas yang tersedia. Terry menjelaskan: "Management is performance of coneiving desired result by means of grouuf efforts consisting of utilizing human talent and resources". Hal Ini memberikan pemahaman bahwa manajemen merupakan kemampuan mengatur dan meraih target yang di rencanakan dengan memberdayakan anggota dan fasilitas-fasilitas yang tersedia. ${ }^{4}$

Menurut Stoner yang dikutip oleh Sufyarma menjelaskan bahwa Manajemen adalah kegiatan perencanaan, pengorganisasian, kepemimpinan dan pengendalian kegiatan dan tindakan anggota organisasi serta penggunaan komponen organisasi untuk meraih target

\footnotetext{
${ }^{3}$ Ujang Andi Yusuf, Kebutuhan Ilmu Manajemen Pendidikan Islami dalam Menjawab Tantangan Era Revolusi 4.0, Islamic Management: Jurnal Manajemen Pendidikan Islam, http://jurnal.staialhidayahbogor.ac.id/index.php/jim/article/view/688/491， (DIakses 07 Juli 2020), 96.

4 Syafaruddin, Manajemen Lembaga Pendidikan Islam, (Jakarta: Ciputat Press, 2005), 41
} 
yang telah ditetapkan. ${ }^{5}$ Ricky W. Griffin mendefinisikan manajemen sebagai suatu tindakan atau aksi perencanaan, dan pengambilan keputusan, pengorganisasian, kepemimpinan, dan pengendalian yang menyasar pada komponen organisasi (manusia, finansial, fisik, dan informasi) dengan tujuan untuk meraih target organisasi. ${ }^{6}$

Dari berbagai macam arti tentang manajemen, dipengeruhi oleh subjektivitas, latarbelakang pendidikan/ pengalaman, dan lingkungan belajar seorang manajer, antara lain: kompetensi dan idealitas menjalankan sebuah perusahaan dan bertanggung jawab atas prestasi maupun kegagalan. Disisi yang lain terdapat anggapan bahwa, manajemen merupakan tindakan merencanakan dan meraih target yang dicanangkan melalui kegiatan memaksimalkan potensi manusia dan sarana prasarana. ${ }^{7}$

Dengan demikian, dapat ditarik kesimpulan bahwa manajemen adalah proses perencanaan (planning), pengorganisasian (organizing), pelaksanaan (actuating) dan evaluasi (evaluating) untuk mencapai tujuan (objek) secara efektif dan efesien. Efektif bermakna target terpenuhi sesuai planning dan efisien bermakna tugas diselesaikan secara tertib, terorganisir, dan sesuai dengan waktu yang telah ditentukan.

Pembelajaran mempunyai arti yang berbeda dengan belajar. Pembelajaran merupakan kegiatan belajar yang difasilitasi oleh guru untuk mengembangkan aspek kognitif yang dapat meningkatkan daya pikir siswa, serta dapat meningkatkan daya dalam mengelola pengetahuan baru. Pembelajaran menjadi sebuah tindakan dalam meningkatkan pemahaman yang signifikan terhadap conten pelajaran.

${ }^{5}$ Erni Sukaesih, Strategi Optimalisasi Manajemen Pengetahuan Berbasis Multi-Generasi Karyawan dalam Upaya Meningkatkan Modal Intelektual di Telkom Regional III Jawa Barat, Jurnal Universitas Pasudan, http://repository.unpas.ac.id/47838/, (Diakses 07 Juli 2020), 5 .

${ }^{6}$ Ujang Andi Yusup, 98.

7 Teni Sutianiwijaya, Pengaruh Motivasi Kerja dan Kompetensi Guru terhadap Kinerja Guru SD di Gugus Nanggala Ciranjang Cianjur, Jurnal Universitas Pasudan, http://repository.unpas.ac.id/48115/, (Diakses 07 Juli 2020), 64. 
Hal ini tentu bertolak belakang dengan makna belajar, yang dapat dimaknai sebuah upaya dalam memperoleh pengetahuan atau ilmu, berlatih, berubah tingkah laku atau tanggapan yang dipengaruhi oleh tindakan atau pengalaman.

Pembelajaran muncul dari konsep belajar. Belajar dimaknai sebagai suatu proses dimana sebuah oganisme berubah karakternya sebagai kausalitas dari terjadinya pola interaksi dan komunikasi. Belajar hakekatnya adalah suatu tindakan yang mengharapkan kesempurnaan tingkah laku individu yang sedang belajar. ${ }^{8}$

Dalam pembelajaran tersirat makna tiap-tiap proses yang direncanakan untuk menfasilitasi individu mempelajari suatu kompetensi dan a new value. Proses pembelajaran menuntut guru untuk mengenali dan menginventarisir intake yang dimiliki peserta didik meliputi bakat, motivasi, latar belakang akademis dan sosial ekonomi, dan lainnya. Informasi yang dimiliki oleh pendidik tentang intake peserta didik menjadi modal utama untuk menyampaikan materi pembelajaran dan menjadi kunci suksesnya aplikasi pembelajaran. ${ }^{9}$

Bahan pelajaran dalam proses pembelajaran hanya merupakan perangsang tindakan pendidik atau guru, juga hanya merupakan tindakan memberikan dorongan dalam belajar yang tertuju pada pencapaian tujuan belajar. Antara belajar dan mengajar dengan pendidikan bukanlah sesuatu yang terpisah atau bertentangan. Justru proses pembelajaran adalah merupakan aspek yang terintegrasi dari proses pendidikan.

Makna pembelajaran di dalam Undang-Undang No. 20 Tahun 2003 tentang Sistem Pendidikan Nasional menyatakan bahwa pembelajaran

\footnotetext{
${ }^{8}$ Nurul Hikmah, Manajemen Implementasi Kurikulum 2013 Pendidikan Agama Islam (PAI) pada MAN 2 Model Banjarmasin dan SMAN 1 Banjarmasin, Institusional Digital Repository, http://idr.uin-antasari.ac.id/13846/, (Diakses 08 Juli 2020), 61.

${ }^{9}$ Ein Maria Olfa, Pengaruh Model Belajar MURDER Terhadap Penguasaan Peserta Didik di MTs PP Tunas Harapan Tembilahan, Al-Mutharahah, http:/ /ojs.diniyah.ac.id/index.php/Al-Mutharahah, (Diakses 08 Juli 2020) 155.
} 
adalah proses interaksi peserta didik dengan pendidik dan sumber belajar pada suatu lingkungan belajar. Dimyati dan Mujiono mendefinisikan pembelajaran sebagai kegiatan guru secara terprogram dan terencana untuk menciptakan suasana aktif bagi peserta didik yang menekankan pada penyediaaan fasilitas belajar. ${ }^{10}$ Pendapat Nana Sudjana, pembelajaran dimaknai sebagai upaya yang sistematis dan sengaja agar terjadi proses interaksi edukatif pendidik dan peserta didik. ${ }^{11}$

Sedangkan Oemar Hamalik memandang Pembelajaran sebagai kombinasi sistematis yang terdiri dari segala komponen manusiawi, perlengkapan, fasilitas, prosedur yang saling terkait dalam mencapai tujuan dari pembelajaran. Terdapat tiga fokus yang urgen tentang pembelajaran yaitu: pertama; Pembelajaran berupa usaha untuk merekayasa situasi dan kondisi belajar bagi peserta didik. Kedua; Pembelajaran berupa upaya mempersiapkan peserta didik menjadi warga Negara yang baik dan menjadi harapan bangsa. Ketiga; Pembelajaran berupa proses pematangan peserta didik agar dapat terjun dan beradaptasi di lingkungan masyarakat. ${ }^{12}$

Dengan demikian dari semua pendapat diatas, dapat ditarik simpulkan bahwa pembelajaran diaplikasikan untuk mengkonstruksi daya fikir dan kemampuan memahami dan menguasai bahan pelajaran, yang mana pengetahuan asalnya dari luar kemudian dikonstruksi dalam

\footnotetext{
${ }^{10}$ Lailatul Maskhuroh dkk, Penerapan Cooperative Learning dalam Pembelajaran Materi Tarikh Berbantukan Internet di SMPN 1 Jombang, URWATUL WUTSQO Vol 09, No 1, Maret 2020, https://jurnal.stituwjombang.ac.id/index.php/UrwatulWutsqo/article/view/142/103, (Diakses 08 Juli 2020), 50.

11 Saifuddin Zuhri, Mutmainah, Pengaruh Kompetensi Sosial Guru dan Pola Asuh Orang Tua terhadap Iklim Belajar di Kelas IX SMP Muhammadiyah Serpong, Tangerang Selatan, Banten, el-Moona Jurnal Ilmu Pendidikan Islam Volume I (2), 2019, http://jurnal.fatahillah.ac.id/index.php/elmoona/article/view/10/10, (Diakses 08 Juli 2020), 160.

${ }^{12}$ Nur Halimah, Telaah Komponen dan Pendekatan Pengembangan Kurikulum, Islamika, http://ejournal.unis.ac.id/index.php/ISLAMIKA/article/view/433/pdf, (Diakses 08 Juli 2020), 74 .
} 
diri peserta didik, sehingga peserta didik mampu menumbuhkembangkan intelektualnya.

Menurut Syaiful Sagala, Konsep manajemen sebagai sebuah proses dalam pembelajaran, dimaknai sebagai suatu usaha dan sikap pimpinan (kepala sekolah) sebagai orang yang memberikan instruksi di sekolah dan usaha maupun tindak tanduk guru sebagai pengelola pembelajaran di kelas dalam rangka meraih target program sekolah dan pembelajaran. ${ }^{13}$

Pembelajaran adalah pola interaksi dan komunikasi antara guru dan peserta didik dengan niat untuk memperoleh pengetahuan, sikap, ketrampilan, atau serta mendalami apa yang dipelajari. ${ }^{14}$ Dalam mengelola pembelajaran, guru sebagai pengelola melaksanakan berbagai langkah kegiatan mulai dari merencanakan, mengorganisasikan, mengaplikasikan dan mengevaluasi pembelajaran dilakukan.

Berdasarkan dari konsep manajemen dan pembelajaran, maka konsep manajemen pembelajaran dapat dipahami sebagai proses mengelola yang meliputi kegiatan planning, organizing, actuating dan evaluating proses membelajaran yang berkaitan dengan seluruh komponen di dalamnya guna meraih tujuan ${ }^{15}$ Menurut Ibrahim Bafadhal Manajemen pembelajaran adalah segala tindakan dalam rangka untuk mencapai proses belajar mengajar yang edukatif, efektif dan efisien. ${ }^{16}$

Dengan demikian dapat disimpulkan bahwa manajemen pembelajaran merupakan penataan semua aktivitas pembelajaran mulai dari proses planning, organizing, actuating dan evaluating, yang meliputi

\footnotetext{
${ }^{13}$ Ein Maria Olfa, 155

14 Satria Nasution, Penerapan Saintifik dapat Meningkatkan Motivasi Belajar Siswa tentang Sistim Gerak pada Manusia Pelajaran IPA di Kelas VIII SMP Negeri 1 Rambah Kab. Rokan Hulu Tahun Pelajaran 2016/2017, Jurnal Edu Sains Vol. 2 No.1 Januari 2019, https://e-journal.upp.ac.id/index.php/JES/article/view/1792, (Diakses 08 Juli 2020), 37. ${ }^{15}$ Ein Maria Olfa, 157

${ }^{16}$ Wika Niati, Peran Guru PAUD dalam Menstimulasi Perkemangan Bahasa Anak pada Kelompok B Usia 5-6 Tahun di TK Darma Wanita Kab. Seluma, Al Fitrah Journal OEarly Childhood Islamic

Education, https:// ejournal.iainbengkulu.ac.id/index.php/alfitrah/article/view/2284/1900, (Diakses 08 Juli 2020), 40.
} 
kurikulum inti dan kurikulum penunjang berdasarkan kurikulum yang telah ditetapkan oleh Kementrian Agama atau Kementrian Pendidikan dan Kebudayaan.

\section{Tujuan Manajemen Pembelajaran}

Setiap organisasi dibentuk dan didirikan pasti menginginkan keberhasilan dan kesuksesan, baik organisasi kemasyarakatan, organisasi keagamaan maupun organisasi yang berupa lembaga pendidikan yang sifatnya sementara ataupun permanen serta berbadan hukum maupun yang tidak berbadan hokum, Harus mengetahui dan memahami apa target yang harus diraih dalam pembentukan organisasi. ${ }^{17}$ Termasuk dalam kategori ini tentang tujuan manajemen pembelajaran.

Tujuan manajemen pembelajaran pada dasarnya merupakan derivasi dari Tujuan Pendidikan Nasional UU No. 20 Tahun 2003 Tentang Sistem Pendidikan Nasional Pasal 3 yang berbunyi, "Pendidikan nasional berfungsi mengembangkan kemampuan dan membentuk watak serta peradaban bangsa yang bermartabat dalam rangka mencerdaskan kehidupan bangsa, bertujuan untuk berkembangnya potensi peserta didik agar menjadi manusia yang beriman dan bertakwa kepada Tuhan Yang Maha Esa, berakhlak mulia, sehat, berilmu, cakap, kreatif, mandiri, dan menjadi warga negara yang demokratis serta bertanggung jawab.

Tim Administrasi Pendidikan UPI menjelaskan bahwa Tujuan manajemen pembelajaran adalah mengelola berbagai kegiatan peserta didik agar berbagai kegiatan tersebut memberikan dampak positif bagi lembaga (sekolah/madrasah). Pembelajaran diharapkan berjalan dengan lancar, tertib dan baik sehingga dapat memberikan support bagi

\footnotetext{
${ }^{17}$ Muhammad Husni Ilham dkk, Pengaruh Pengelolaan Kelas oleh Guru terhadap Minat Belajar Siswa Kelas VIII Mata Pelajaran Sejarah Kebudayaan Islam (SKI) Madrasah Tsanawiyah (MTs) An-Nur Kota Cirebon, Al-Tarbawi Al-Haditsah: Jurnal Pendidikan Islam, http://www.syekhnurjati.ac.id/jurnal/index.php/tarbawi/article/view/4078/2315, (Diakses 09 Juli 2020), 52.
} 
pencapaian target sekolah dan target pendidikan secara umum. ${ }^{18}$ Secara khusus tujuan manajemen pembelajaran meliputi dua hal, yaitu:

1. Tujuan bagi peserta didik:

a. Mendidik peserta didik untuk menjadi lebih tanggung jawab terhadap dirinya sendiri atas perilaku dan tindakannya.

b. Menyadarkan peserta didik bahwa setiap arahan dan instruksi pendidik kepada peserta didik untuk bertingkah laku sesuai dengan tata tertib kelas merupakan kasih sayang dan bukan sebuah kemarahan dan arogansi pendidik.

c. Menggugah sikap tanggung jawab dan disiplin peserta didik akan tugas dan kewajibannya.$^{19}$

Point-point di atas memberikan pemahaman agar setiap anak disaat kegiatan pembelajaran dapat tanggung jawab dan disiplin dalam rangkan meraih target pembelajaran secara komprehensif.

2. Tujuan untuk pendidik:

a. Memberikan pemahaman dalam pelaksanaan pelajaran dengan baik dan tepat.

b. Memberikan pemahaman akan hak siswa dan mempunyai kompetensi dalam mengarahkan secara tepat terhadap peserta didik.

c. Memahami langkah-langkah yang mesti diterapkan untuk melayani peserta didik yang bertingkah laku mengganggu.

\footnotetext{
${ }^{18}$ Muhsin, The Effect of The Head Master of Principal's Democratic Leadership Style on Motivation of Teacher Work in State of Madrasah Aliyah-Tapaktuan, Budapest International Research and Critics in Linguistics and Education (BirLE) Journal Volume 2, No 1, February 2019, 165.

19 Setia Budi, Penerapan Model Pembelajaran TGT Dalam Upaya Meningkatkan Minat Dan Hasil Belajar Siswa pada Pokok Bahasan BRSL Di SMP Negeri 2 Stabat, Seminar Nasional Matematika dan Terapan 2019, http://bulletin.indomsacehsumut.org/index.php/simantap/article/download/55/36, (Diakses 09 Juli 2020), 12.
} 
d. Memiliki keahlian dan kompetensi dalam meremidi dan memperbaiki sikap dan tingkah laku peserta didik yang menyimpang ketika proses pembelajaran.

Point-point di atas memberikan pemahaman bahwa setiap pendidik wajib mampu mengelola kegiatan pembelajaran dengan menerapkan macam-macam startegi dan metode dengan menyesuaikan kasus perkasus, sehingga dapat diwujudkan kegiatan pembelajaran yang aktif, inovatif, kreatif, efektif dan menyenangkan.

Terdapat empat manfaat tujuan menejemen pembelajaran, diantaranya:

1. Memudahkan dalam menyampaikan tujuan kegiatan belajar mengajar kepada peserta didik, sehingga peserta didik dapat belajar dengan mandiri;

2. Mempermudah pendidik dalam mengkodisikan penyusunan bahan ajar;

3. Mempemudah pendidik dalam menentukan dan memilih kegiatan dan media pembelajaran yang sesuai karakter materi;

4. Membantu dan mempermudah pendidik dalam melakukan penilaian terhadap proses pembelajaran dan hasil ujian peserta didik. ${ }^{20}$

Dengan demikian, kesimpulan dari tujuan utama manajemen pembelajaran yaitu mencetak kepribadian peserta didik yang sesuai dengan tujuan pendidikan nasional. Secara rinci tujuan menejemen pembelajaran meliputi hal-hal berikut, yaitu: Pertama; Terwujudnya proses pembelajaran yang aktif, inovatif, kreatif, efektif dan menyenangkan. Kedua; Terciptanya peserta didik aktif mengembangkan minat dan bakatnya dalam rangka meraih kedalaman spiritual keagamaan, kompetensi profesional, memiliki kecakapan dan kecerdasan,

${ }^{20}$ Nur Jannah, Syarifatul Marwiyah, Model Pengembangan Kurikulum Adaptif pada Madrasah Ibtidaiyah Inklusif, Jurnal Auladuna, http://ejournal.inaifas.ac.id/index.php/auladuna/article/view/300/239, (Diakses 09 Juli 2020), 91. 
berakhlak mulia, serta terampil memposisikan diri dalam bermasyarakat, bangsa dan negara. Ketiga; Terlaksananya kegiatan belajang mengajar yang efektif, efisien, bermutu, dan akuntabel.

\section{Unsur Unsur Manajemen Pembelajaran}

Unsur-unsur manajemen, pada umumnya meliputi tujuh unsur manajemen yang di singkat $6 \mathrm{M}+\mathrm{I}$, diantaranya man, money, material, machine, method, market dan information. ${ }^{21}$

1. Manusia/Man

Sumber daya manusia adalah salah satu faktor produksi selain tanah, modal, dan life skill di dalam pendekatan ekonomi,. Manusia merupakan unsur manajemen yang sangat penting keberadaannya dalam rangka meraih target. Oleh karana itu, seorang pendidik memiliki peranan yang sangat urgen dalam pembelajaran.

2. Uang/ Money

Sebuah perusahaan sangat penting untuk memiliki stabilitas keuangan yang kuat, karena berbagai kegiatan perusahaan membutuhkan dan memerlukan biaya operasinal yang besar. Mulai dari perizinan, pembuatan gedung kantor, mesin produksi dan perlengkapannya, upah buruh, pengadaan bahan baku, dan biaya akomodasi. Owner perusahaan menyiapkan pendanaan yang besar untuk modal produksi. Begitu juga halnya didalam dunia pendidikan, keuangan yang dimiliki oleh lembaga pendidikan juga akan memberikan dampak dan pengaruh yang signifikan terhadap keberhasilan untuk meningkatkan mutu pembelajaran.

3. Bahan Baku/ Material

Point ini merupakan gambaran input (peserta didik) yang akan mendapatkan proses pembinaan, pembimbingan dan pendidikan selama proses belajar mengajar berlangsung baik teori maupun praktek.

${ }^{21}$ Teni Sutianiwijaya, 64. 
4. Mesin/Machine

Perwujudan mesin ini adalah sarana dan prasaran yang disiapkan oleh sekolah sebagai salah satu faktor penunjang dalam rangkan mempermudah dan meningkatkan kualitas pembelajaran. Selain itu, penciptaan atau setting suasana lingkungan yang baik dan kondusif juga menjadi motor penggerak dalam rangka untuk mencapai hasil pembelajaran yang maksimal sesuai dengan tujuan manajemen pembelajaran

5. Metode/ Methode

Metode kerja sangat dibutuhkan agar mekanisme kerja berjalan efektif dan efisien. Begitu juga dalam pembelajaran, Terdapat bermacam-macam metode pembelajaran. Setiap metode memiliki kelebihan dan kekurangan, sehingga pendidik harus pintar dan kreatif dalam memilih metode pembelajaran. Penggunaan dan penerapan metode oleh guru harus sesuai dengan karakter materi dan karekter peserta didik dalam rangka memenuhi target pembelajaran.

6. Pasar/ Market

Pasar merupakan masyarakat (pelanggan). Saat ini pasar sudah berkali-kali mengalami perubahan dan pergeseran. Pengaruh globalisasi menjadi tantangan yang harus di hadapi, mulai dari bidang keuangan, kebudayaan, etika dan moral. Sehingga manajemen pembelajaran sudah harus mengarah dan menjawab tantangan tersebut. 22

7. Informasi/ Information

informasi (serap aspirasi) harus selalu up to date di sebuah perusahaan. Informasi tentang kecenderungan dan sesuatu yang sedang popular di masyarakat. Menggali, mengumpulkan dan mengelola informasi sangat urgen juga dalam menganalis produk

${ }^{22}$ Muhaimin, Nuansa Baru Pendidikan Islam; Mengurai Benang Kusut Penddikan Islam, (Jakarta: PT. Raja Grafindo Persada, 2006), 84. 
yang telah dan akan dipasarkan. Sehingga informasi menjadi salah satu pertimbagan dalam rangka pemutakhiran proses pembelajaran.

\section{Prinsip-Prinsip Menajemen Pembelajaran}

Setiap pendidik yang baik dan professional harus memiliki prinsip dalam mengelola pembelajaran. Prinsip-prinsip yang dijadikan pijakan dalam mengaplikasikan kegiatan belajar mengajar secara efektif, efesien dan akuntabel. Diantara prinsip-prinsip yang dimaksud meliputi:

1. Perhatian

Proses pembelajaran hendaknya tidak mengabaikan masalah perhatian peserta didik. Pendidik wajib untuk bisa menarik dan mengambil hati peserta didik agar dapat berkonsentrasi dan tertarik pada materi pelajaran yang sedang diajarkan serta guru juga harus berenampilan yang baik dan bersikap menyenangkan sebagai teladan.

2. Motivasi

Peserta didik memerlukan motivasi intrinsik dan ekstrinsik. Motivasi intrinsik diperlukan oleh peserta didik karena kegiatan belajar mengajar kurang efektif tanpa kesiapan aspek fisiologis dan biologis. Motivasi ekstrnsik berasal dari luar/pendidik. ${ }^{23}$ Jika perhatian peserta didik sudah fokus maka pendidik dapat memotivasi peserta didik. Pendidik harus dapat menumbuhkan dan menguatkan motivasi peserta didik sepanjang kegiatan belajar mengajar berlangsung.

3. Keaktifan peserta didik

Kegiatan Pembelajaran bermakna jika peserta didik proaktif dalam kegiatan belajar mengajar. Sebagai subjek peserta didik tidak hanya menerima materi pembelajaran, akan tetapi peserta didik proaktif beraktivitas. khusus hal ini pendidik sedapat mungkin merekayasa

\footnotetext{
$23 \mathrm{Ni}$ Luh Suyantini, Penerapan Model Pembelajaran Quantum Teaching untuk Meningkatkan Hasil Belajar IPA Siswa Kelas IX-E Semester Ganjil SMP Negeri 2 Kubu Tahun Pelajaran 2017/2018, Jurnal IKA Vol. 17, No. 1 Maret 2019, https:// ejournal.undiksha.ac.id/index.php/IKA/article/view/19840/12652, (Diakses 10 Juli 2020), 77.
} 
situasi dan kondisi yang memberikan stimulus aktivitas siswa yang kreatif.

4. Keterlibatan Langsung

Penting untuk dipahami oleh pendidik bahwa peserta didik harus terjun dan terlibat langsung dalam kegiatan pembelajaran. Oleh karena itu, pendidik perlu merekayasa situasi dan kondisi yang sejalan dengan target pembelajaran.

5. Pengulangan Belajar.

Dalam kegiatan membaca, mempelajari, memahami dan menganalisis konten pembelajaran yang dialami oleh peserta didik tidak bisa berlangsung secara instan dan cepat, karena minat dan bakat tiap-tiap individu peserta didik berbeda-beda sehingga perlu melakukan pengulangan. Pengulangan diterapkan untuk memberikan pemantapan terhadap pesrta didik supaya meteri yang dipelajari tetap ingat. Dengan demikian, pendidik hendaknya menyediakan waktu khusus bagi peserta didik untuk penguatan belajar baik teori maupun praktek.

6. Materi Pelajaran yang Merangsang dan Menantang

Untuk menghindari kepenatan dan rasa bosan peserta didik pada saat kegiatan belajar mengajar, pendidik sedapat mungkin menggunakan metode dan startegi yang beragam yang sesuai dengan karekter materi. Materi disiapkan dan diorganisasikan kembali oleh guru. Hal ini diharapkan dapat memberikan stimulus dan tantangan terhadap peserta didik untuk memahami dan mempelajari kembali materimateri yang telah diajarkan.

7. Reinforcement atau Penguatan kepada Siswa.

Reinforcement memiliki efek social yang tidak bisa diremehkan jika disajikan kepada peserta didik. Sekecil apapun prestasi peserta didik, hendaknya dirayakan dan diberi penghargaan sesuai dengan prestasinya itu. 


\section{Implementasi Manajemen Pembelajaran Dalam Meningkatkan} Efektivitas Proses Belajar Mengajar di Masa Pandemi Covid-19

Surat Keputusan Menteri Kesehatan yang berhubungan dengan kebijakan New Normal dengan nomor No.HK.01.07/MENKES/328/2020, tentang panduan pencegahan dan pengendalian Covid-19 di dunia usaha dan dunia industri dalam mendorong keberlangsungan usaha di masa pandemi. Peraturan ini berlaku di semua lini kehidupan, termasuk di dalamnya dunia pendidikan yang sudah beberapa bulan ini dilakukan kebijakan belajar dari rumah.

Selain kemenkes tersebut juga SE. Mendikbud No. 4 Tahun 2020 tentang Pelaksanaan Kebijakan Pendidikan dalam Masa Darurat Penyebaran Corona Virus Disease (COVID-19), SK. Dirjen Pendis No. 3063 Tahun 2019 tentang Kalender Pendidikan Madrasah Tahun Pelajaran 2019/2020, SK. Dirjen Pendis No. 2491 Tahun 2020 tentang Kalender Pendidikan Madrasah TP. 2020/2021, dan SK. Dirjen Pendis No. 2791 Tahun 2020 tentang Panduan Kurikulum Darurat pada Madrasah.

Oleh karena itu, Kementerian Pendidikan dan Kebudayaan (Kemendikbud) merencanakan untuk kembali membuka kegiatan sekolah di masa pandemi Covid-19. Rancangan ini akan lending di bulan Juli atau awal tahun ajaran baru 2020/2021. Diaktifkannya lembaga pendidikan di masa New Normal ini merupakan ide dan wacana baru di dunia pendidikan, karena dunia pendidikan adalah instansi yang memobilisasi masa yang jumlahnya sangat besar dan masif. Ditambah lagi generasi yang masih usia anak-anak dan remaja yang menjadi populasi padat sektor pendidikan, yang dikawatirkan sangat efektif menularkan virus.

Pemerintah melalui kementrian yang bergerak dibidang pendidikan telah menginstruksikan kepada para pendidik untuk menciptaan suasana pembelajaran yang mengasikkan dari rumah bagi peserta didik. Oleh karena itu, pendidik seharusnya lebih kreatif lagi dalam memberikan materi pembelajaran jarak jauh (PJJ), sehingga murid 
tak hanya mengerjakan tugas-tugas atau persoalan-persoalan akademis (transfer of knowladge) saja, akan tetapi juga perlu diperhatikan nilai-nilai karakternya (transfer of value). Pendidik harus bisa menyiapkan kegiatan pembelajaran yang menyenangkan dan menantang agar minat belajar peserta didik tetap antusias.

\section{Faktor-Faktor yang Mempengaruhi Manajemen Pembelajaran dalam} Meningkatkan Efektivitas Proses Belajar Mengajar di Era Pandemi

\section{Covid-19}

Pada tataran praktis manajemen pembelajaran yang diimplementasikan oleh pendidik menemui banyak hambatan. Hambatan yang dimaksud tentang kewenangan pengelolaan secara umum dan khusus. Pengelolaan secara umum meliputi:

1. Hal-hal yang berkaitan dengan wewenang guru.

2. Hal-hal yang berkaitan dengan wewenang sekolah sebagai institusi.

3. Hal-hal yang kebijakannya tidak ditentukan oleh guru mata pelajaran dan institusi sekolah.

Pengelolaan secara khusus dapat diklasifikasikan menjadi empat kategori, yaitu:

1. Faktor guru;

Faktor kompetensi guru dalam mengelola pembelajaran sangatlah urgen dalam meningkatkan efektifitas proses belajar mengejar di era pandemic covid-19. Pembelajaran menjadi tidak maksimal ketika pembelajaran monoton (bersifat seremonial), uswah pendidik yang tidak religius, pemahaman dan pengertian pendidik yang tidak komplit tentang pembelajaran baik daring maupun luring, serta informasi pendidik tentang peserta didik yang tidak lengkap, baik peserta didik sebagai seorang pribadi mapun sebagai sebagai bagian dari anggota keluarganya.

2. Faktor peserta didik.

Kurangnya tanggung jawab peserta didik dalam melaksanakan dan menyelesaikan tugasnya sebagai peserta didik yang tetap wajib belajar 
selama belajar dari rumah. Peserta didik merasa bosan dengan kebiasaan belajar yang baru. Selama di rumah peserta didik tetap wajib belajar baik daring maupun luring yang di pandu oleh guru dan didampingi oleh orang tua.

3. Faktor keluarga.

Orang tua yang selama ini hanya pasrah ke pihak sekolah/ guru dalam hal pembelajaran, saat ini mau tidak mau harus mengawal dan memantau sendiri anak-anaknya selama belajar di rumah. Keluarga yang acuh tah acuh terhadap kegiatan belajar dari rumah menjadi hambatan bagi peserta didik dan guru dalam proses belajar mengajar. Keluarga peserta didik yang setiap harinya harus bekerja kesulitan untuk mengawal dan memantau peserta didik yang belajar dari rumah.

4. Faktor fasilitas.

Di era pandemi covid-19 fasilitas yang berupa alat-alat atau fasilitas yang berbasis teknologi sangat dibutuhkan dan harganya oleh sebagaian besar orang tua peserta didik sulit untuk dijangkau dalam menyiapkan fasilitas pembelajaran jarak jauh (PJJ). Diantaranya fasilitas laptop, hendphone yang berbasis android, dan penyediaan dana tambahan untuk membeli kuota internet yang berkala selama pandemic covid-19 untuk fasilitas pembelajaran daring.

\section{Peran Guru Dalam implementasi Manajemen Pembelajaran Dalam} Meningkatkan Efektivitas Proses Belajar Mengajar di Era Pandemi

\section{Covid-19}

Sebagai ujung tombak dan garda terdepan saat kegiatan belajar mengajar, pendidik harus tetap bisa menghadirkan pembelajaran yang aktif, inovatif, kreatif, efektif, menyenangkan dan efisien, serta mengandung nilai transfer of knowledge dan transfer of value.

Oleh karena itu, selama masa pandemi covid-19 ini peranan pendidik sangat urgen dalam memanage pembelajaran jarak jauh (PJJ) baik daring maupun luring. Untuk menjamin kualitas pembelajaran, maka 
pendidik semaksimal mungkin mengelola pembelajaran mulai dari perencanaan (planning), pengorganisasian (organizing), pelaksanaan (actuating) dan evaluasi (evaluating). ${ }^{24}$

1. Perencanaan (planning)

Perencanaan/ planning merupakan kegiatan yang paling mendasar dalam berbagai kegiatan yang bentuknya tindakan mengakomodir segala sesuatu yang berkaitan dengan pekerjaan itu untuk meraih target/tujuan yang optimal. Planning is the first step to any course of action which decides the strategy as how to attain maximum outcome from such action. ${ }^{25}$ Perencanaan merupakan penetapan segenap tindakan dan sumber daya dalam upaya maraih target/tujuan.

Dalam membuat dan menetapkan keputusan tentang kegiatan pembelajaran, pendidik sebagai pengelola kegiatan pembelajaran tentunya sudah menyiapkan alternatif-alternatif pilihan untuk meraih tujuan. Selain itu, Pendidik juga harus mampu mengelola multi sumber, baik sumber daya, sumber dana, maupun sumber belajar. ${ }^{26}$ Bagi pendidik manfaat perencanaan sebagai kontrol terhadap diri sendiri supaya dapat memperbaiki pola pengajaran dan sebagai pijakan baginya. ${ }^{27}$

Jadi, di era pandemic covid-19 ini, perencanaan pembelajaran minimal meliputi; 1) memilih dan menetapkan tindakan pendidik, kapan

\footnotetext{
${ }^{24}$ Alfian Erwinsyah, Manajemen Kelas dalam Meningkatkan Efektifitas Proses Belajar Mengajar, TADBIR: Jurnal Manajemen Pendidikan Islam Volume 5, Nomor 2: Agustus 2017, http://journal.iaingorontalo.ac.id/index.php/tjmpi/article/view/392, (Diakses 10 Juli 2020) 98.

${ }^{25}$ Didin Hafidhuddin, Hendri Tanjung, Shariah Principles on Management in Practice, (Jakarta: Gema Insani Press, 2006), 87

26 E. Mulyasa, Pedoman Manajemen Berbasis Madrasah, (Proyek Pemberdayaan Kelembagaan dan Ketatalaksanaan Pada Madrasah dan PAI pada Sekolah Umum Tingkat Dasar: 2004), 27

27 Laksamana Arnanda Harahap, Kompetensi Guru Pendidikan Agama Islam dalam Mengelola Kelas dan Mengatasi Kesulitan Belajar Peserta Didik di SMA Negeri Se-Kota Pekanbaru, Tesis, Pascasarjana Universitas Islam Negeri Sultan Syarif Kasim Riau 1441/2020, http://repository.uinsuska.ac.id/29640/1/TESIS\%20LAKSAMAN\%20ARNANDA\%20HARAHAP.pdf, (Diakses 11 Juli 2020), 40.
} 
dan bagaimana cara mengimplementasikannya, 2) membatasi dan menetapkan pelaksanaan kerja sesuai target pembelajaran; 3) inovasi strategi pembelajaran; 4) menganalisis situasi dan kondisi untuk tercapainya implementasi pembelajaran. 5) mengkomunikasikan perencanaan yang terkait dengan pembelajaran kepada pihak-pihak yang berwenang.

2. Pengorganisasian (organizing)

Pengorganisasian dalam menejemen pembelajaran menempati posisi yang strategis karana menjadi kompas pendidik dalam memenuhi tugas profesionalnya sebagai pendidik ketika memberikan layanan pendidikan kepada peserta didik. Kegiatan pengorganisasian pembelajaran dimaksudkan untuk menenntukan tugas pokok dan fungsi masing-masing sesuai prinsip organisasi, dengan mendelegasikan setiap personil sekolah sesuai kompetensi, mata pelajaran, wewenang, dan tanggung jawabnya masing-masing.

Pengorganisasian pembelajaran menjadi tolak ukur kegiatan pembelajaran supaya arah dan penanggung jawabnya jelas. Hal ini memungkinkan kedudukan kepala sekolah sebagai mananjer dalam menyiapkan sarana dan prasarana pembelajaran, jelas tugas dan fungsi pendidik untuk memilih dan mendesain kegiatan pembelajaran sesuai dengan distribusi waktu, rekayasa kurikulum, media dan komponen pembelajaran serta yang berkaitan dengan peningkatan efektifitas prose belajar mengajar di era pandemic covid-19.

3. Pelaksanaan (actuating)

Dari berbagai fungsi dalam manajemen, pelaksanaan (actuating) adalah fungsi yang paling utama. Fungsi perencanaan dan pengorganisasian hanya menjadi tataran konsep abstrak proses manajemen, dan fungsi actuating terkait langsung dengan para pelaksana di dalam organisasi. Actuating merupakan implementasi planning dengan 
pijakan organizing. ${ }^{28}$ Pelaksanaan (actuating) merupakan perwujudan dari perencanaan yang sudah melalui berbagai seleksi dan analisa agar dapat mewujudkan dan menerapkan pembelajaran yang maksimal dan kondusif.

Pelaksanaan proses belajar mengajar di era pandemic covid-19 harus memegang prinsip-prinsip yang termaktub dalam SE. Menteri Pendidikan dan Kebudayaan Nomor 4 Tahun 2020 tentang Pelaksanaan Kebijakan Pendidikan dalam Masa Darurat Penyebaran Corona Virus Disease (COVID-19), yaitu:

1. Keselamatan dan kesehatan jasmani dan rohani peserta didik, pendidik, kepala institusi pendidikan dan seluruh warga institusi pendidikan menjadi acuan pertama dan utama selama menerapkan Belajar Dari Rumah (BDR);

2. Kegiatan BDR diterapkan untuk menanamkan karakter istiqomah dalam belajar, tanpa harus menyelesaikan seluruh capaian kurikulum;

3. BDR berfokus pada life skill, khususnya tentang pandemi COVID19;

4. Konten pembelajaran menyesuaikan dengan usia dan jenjang pendidikan, religious culture, karakter dan ciri khas peserta didik;

5. Pembelajaran disesuaikan dengan situasi dan kondisi masingmasing daerah, apalagi yang berkaitan dengan fasilitas BDR;

6. Penugasan dan Penilaian BDR bersifat kualitatif; dan

7. Pendidik dengan orang tua/ wali peserta didik menjalin komunikasi yang aktif dan positif. ${ }^{29}$

\footnotetext{
${ }^{28}$ Wibowo, Manajemen Perubahan, (Jakarta: RajaGranfindo Persada, 2013). Hal.116 29 Surat Edaran Menteri Pendidikan dan Kebudayaan Nomor 4 Tahun 2020 tentang Pelaksanaan Kebijakan Pendidikan dalam Masa Darurat Penyebaran Corona Virus Disease (COVID 19), https://pusdiklat.kemdikbud.go.id/surat-edaran-mendikbud-no-4-tahun2020-tentang-pelaksanaan-kebijakan-pendidikan-dalam-masa-darurat-penyebarancorona-virus-disease-covid-1-9/, (Diakses 11 Juli 2020).
} 
Pendidik sebagai penanggung jawab langsung proses belajar mengajar dapat menentukan Pelajaran Jarak Jauh dengan pertimbangan pertama; Pendidik memilih dan menentukan mata pelajaran prioritas dan mengintruksikan kepada peserta didik agar selanjutnya belajar secara mandiri, kedua; pendidik menentukan metode yang tepat sesuai materi pembelajaran, Ketiga; pendidik selektif dalam memilih/ memanfaatkan media/sumber belajar yang ada di lingkungan sekitar.

Pendekatan Pembelajaran Jarak Jauh (PJJ) ada 2 (dua) pendekatan yang meliputi Pembelajaran jarak jauh dalam jaringan (daring) dan Pembelajaran jarak jauh luar jaringan (luring). Pada tataran implementasi PJJ, satuan pendidikan dipersilahkan untuk menerapkan (daring atau luring atau konvergensi keduanya) berdasarkan kesiapan dan kemampuan lembaga pendidikan. Sarana dan prasarana Pembelajaran Jarak Jauh Daring dapat memanfaatkan gawai (gadget) maupun laptop melalui beberapa portal dan aplikasi pembelajaran daring. Proses pembelajaran daring terdiri atas: pertama; tatap muka Virtual melalui video conference, teleconference, dan/atau diskusi dalam group di media sosial atau aplikasi pesan. Dalam hal ini pendidik dengan peserta didik dapat berinteraksi secara langsung. Kedua; Learning Management System (LMS). LMS merupakan sistem pengelolaan pembelajaran terintegrasi secara daring melalui aplikasi. Aktivitas pembelajaran dalam LMS antara lain pendaftaran dan pengelolaan akun, penguasaan materi, penyelesaian tugas, pemantauan capaian hasil belajar, terlibat dalam forum diskusi, konsultasi dan ujian/penilaian. Contoh LMS antara lain kelas maya rumah belajar, google classroom, edmodo, moodle, zenius ruang guru, siajar LMS seamolec, dan lain sebagainya.

Sedangkan Pembelajaran Luring dapat menggunakan media buku, modul dan bahan ajar dilingkunan sekitar lembaga, bisa dengan media televisi, radio daerah dan lain sebagainya. Waktu pembelajaran daring dan luring sepanjang hari menyesuaikan ketersediaan waktu, kondisi, dan 
kesepakatan peserta didik dan orangtua/walinya dengan memperhatikan protokol kesehatan.

4. Pengawasan (Controlling).

Pendidik melaksanakan kontrol terhadap program yang disusunnya sendiri, apakah sesuai dengan yang ditetapkannya. Pengawasan meliputi supervisi, dan menilai pelaksanaan terhadap standar dan mendukung tercapainya tujuan pembelajaran. ${ }^{30}$ Jika terdapat kesalahan atau ada program yang tidak sesuai target maka segera direvisi dalam perencanaanya, sehingga tujuan yang ditentukan sebelumnya dapat tercapai maksimal.

Kegiatan Pengawasan dilakukan pendidik dalam rangka mencari informasi, menganalisis informasi, dan mengevaluasi data-data yang berkaitan dengan kegiatan belajar serta menggunakannya untuk mengontrol kegiatan pembelajaran untuk meraih target belajar. Pembenahan dilakukan pada saat proses belajar mengajar dan juga pada proses pembelajaran selanjutnya sebagai bagian dari control pembelajaran yang diterapkan oleh pendidik.

Selain pengawasan atau evaluasi terhadap program pembelajaran, pendidik juga melakukan pengawasan terhadap pencapaian kompetensi peserta didik. Pengawasan terhadap pencapaian kompetensi peserta didik laksanakan dengan penyesuaian pada ketentuan kondisi darurat pandemi covid-19 berikut ini

a. Penilaian Hasil Belajar yang berupa Penilaian Harian (PH) dan Penilaian Akhir Semester (PAS) termasuk pelaksanaan Penilaian Perkembangan Anak (PPA) pada PAUD dan TK/RA dapat dilakukan tanpa harus mengumpulkan siswa;

b. PH dan PAS dilakukan dalam bentuk tugas-tugas yang memungkinkan dilakukan secara jarak jauh dan diambil dari nilai

\footnotetext{
${ }^{30}$ Risnayanti, Implementasi Pendidikan Agama Islam Di Taman Kanak-Kanak Islam Ralia Jaya Villa Dago Pamulang, (Jakarta: Perpustakaan Umum, 2004), 15-17
} 
rapor dan prestasi yang diperoleh sebelumnya. Khusus pada anak RA pemantauan penilaian perkembangan anak diperoleh melalui konsultasi/komunikasi antara guru dengan orang tua dan tetap mematuhi konsep menitikberatkan pada aspek perkembangan anak dan bukan aktivitas akademis;

c. PH dan PAS, termasuk PPA pada PAUD dan TK/RA dilaksanakan sebagai formalitas yang tidak mengurangi nilai pendidikan karakter dan tidak perlu diukur dengan capaian kurikulum atau STPPA pada PAUD dan TK/RA secara menyeluruh;

d. Konsep menghitung nilai raport pada semua jenjang pendidikan (SD/MI,SMP/MTs,SMA/SMK/MA) atau PPA pada PAUD dan TK/RA tetap berpedoman pada ketentuan yang berlaku di sekolah/madrasah dengan penyesuaian pada ketentuan kondisi darurat.

\section{Kesimpulan}

Di masa darurat penyebaran corona virus disease (COVID-19), manajemen pembelajaran dalam meningkatkan efektivitas proses belajar mengajar mempunyai posisi yang sangat urgen, karena kegiatan belajar dituntut untuk tetap memberikan pelayanan yang prima dan terbaik sesuai standar pendidkan dan juga harus mengikuti protokol kesehatan yang sudah disepekati oleh empat mentri (SKB 4 Mentri), sebab di masa darurat penyebaran Corona Virus Disease (COVID-19) peran guru dalam mengolah pembelajaran dalam meningkatkan efektivitas proses belajar mengajar sangat signifikan. Artinya guru harus dapat mengelola pembelajaran mulai dari perencanaan (planning), pengorganisasian (organizing), pelaksanaan (actuating) dan evaluasi (evaluating) untuk menjamin proses belajar mengajar yang baik, efektif dan efisien pada saat pembelajaran jarak jauh, baik secara dalam jaringan (daring) maupun luar jaringan (luring). 


\section{Referensi}

A. Marjuni, Hamzah Harun, Penggunaan Multimedia Online dalam Pembelajaran, Jurnal Idaarah, vol. III, No. 2, Desember 2019, (Diakses 07 Juli 2020).

Jojo Warjo dkk, Implikasi Gaya Berpikir dan Interaksi Sosial Siswa pada Pembelajaran Model Kooperatif Berbasis Media Informasi dan Komunikasi Terhadap Prestasi Belajar Siswa, Edubiologica, Vol. 6, No. 1, Juni 2018, pp. 14-19, (Diakses 07 Juli 2020), 16.

Ujang Andi Yusuf, Kebutuhan Ilmu Manajemen Pendidikan Islami dalam Menjawab Tantangan Era Revolusi 4.0, Islamic Management: Jurnal Manajemen Pendidikan Islam, http:/ /jurnal.staialhidayahbogor.ac.id/index.php/jim/article/vie w/688/491, (DIakses 07 Juli 2020), 96.

Syafaruddin, Manajemen Lembaga Pendidikan Islam, (Jakarta: Ciputat Press, 2005), 41

Ernisukaesih, Strategi Optimalisasi Manajemen Pengetahuan Berbasis Multi-Generasi Karyawan dalam Upaya Meningkatkan Modal Intelektual di Telkom Regional III Jawa Barat, Jurnal Universitas Pasudan, http://repository.unpas.ac.id/47838/, (Diakses 07 Juli 2020), 5 .

Teni Sutianiwijaya, Pengaruh Motivasi Kerja dan Kompetensi Guru Terhadap Kinerja Guru SD di Gugus Nanggala Ciranjang Cianjur, Jurnal Universitas Pasudan, http://repository.unpas.ac.id/48115/, (Diakses 07 Juli 2020), 64.

Nurul Hikmah, Manajemen Implementasi Kurikulum 2013 Pendidikan Agama Islam (PAI) Pada MAN 2 Model Banjarmasin dan SMAN 1 Banjarmasin, Institusional Digital Repository, http://idr.uinantasari.ac.id/13846/, (Diakses 08 Juli 2020), 61.

Ein Maria Olfa, Pengaruh Model Belajar MURDER Terhadap Penguasaan Peserta DidikDi MTs PP Tunas Harapan Tembilahan, AlMutharahah, http://ojs.diniyah.ac.id/index.php/Al-Mutharahah, (Diakses 08 Juli 2020) 155.

Lailatul Maskhuroh dkk, Penerapan Cooperative Learningdalam Pembelajaran Materi Tarikh Berbantukan Internet di SMPN 1 Jombang, Urwatul Wutsqo Vol 09, No 1, Maret 2020, https://jurnal.stituwjombang.ac.id/index.php/UrwatulWutsqo/ar ticle/view/142/103, (Diakses 08 Juli 2020), 50. 
Saifuddin Zuhri, Mutmainah, Pengaruh Kompetensi Sosial Guru dan Pola Asuh Orang Tua terhadap Iklim Belajar di Kelas IX SMP Muhammadiyah Serpong, Tangerang Selatan, Banten, El-Moona Jurnal Ilmu Pendidikan Islam Volume I (2), 2019, http://jurnal.fatahillah.ac.id/index.php/elmoona/article/view/10 /10, (Diakses 08 Juli 2020), 160.

Nur Halimah, Telaah Komponen dan Pendekatan Pengembangan Kurikulum, Islamika, http:/ / ejournal.unis.ac.id/index.php/ISLAMIKA/article/view/43 3/pdf, (Diakses 08 Juli 2020), 74.

Satria Nasution, Penerapan Saintifik dapat Meningkatkan Motivasi Belajar Siswa tentang Sistim Gerak pada Manusia Pelajaran IPA di Kelas VIII, SMP Negeri 1 Rambah Kab. Rokan Hulu Tahun Pelajaran 2016/2017, Jurnal Edu Sains Vol. 2 No.1 Januari 2019, https://ejournal.upp.ac.id/index.php/JES/article/view/1792, (Diakses 08 Juli 2020), 37.

Wika Niati, Peran Guru PAUD dalam Menstimulasi Perkemangan Bahasa Anak pada Kelompok B Usia 5-6 Tahun Di TK Darma Wanita Kab. Seluma, Al Fitrah Journal OEarly Childhood Islamic Education, https:/ / ejournal.iainbengkulu.ac.id/index.php/alfitrah/article/vie w/2284/1900, (Diakses 08 Juli 2020), 40.

Muhammad Husni Ilham dkk, Pengaruh Pengelolaan Kelas oleh Guru terhadap Minat Belajar Siswa Kelas VIII Mata Pelajaran Sejarah Kebudayaan Islam (SKI) Madrasah Tsanawiyah (MTs) AN-NUR Kota Cirebon, Al-Tarbawi Al-Haditsah: Jurnal Pendidikan Islam, http://www.syekhnurjati.ac.id/jurnal/index.php/tarbawi/article / view/4078/2315, (Diakses 09 Juli 2020), 52.

Muhsin, The Effect of The Head Master of Principal's Democratic Leadership Style on Motivation of Teacher Work in State of Madrasah Aliyah-Tapaktuan, Budapest International Research and Critics in Linguistics and Education (BirLE) Journal Volume 2, No 1, February 201Budapest International Research and Critics in Linguistics and Education (BirLE) Journal Volume 2, No 1, February 2019, 165.

Setia Budi, Penerapan Model Pembelajaran TGT Dalam Upaya Meningkatkan Minat Dan Hasil Belajar Siswa Pada Pokok Bahasan BRSL Di SMP Negeri 2 Stabat, Seminar Nasional Matematika dan Terapan 2019, http://bulletin.indomsacehsumut.org/index.php/simantap/article/download/55/36, (Diakses 09 Juli 2020), 12. 
Nur Jannah, Syarifatul Marwiyah, Model Pengembangan Kurikulum Adaptif pada Madrasah Ibtidaiyah Inklusif, Jurnal Auladuna, http:/ / ejournal.inaifas.ac.id/index.php/auladuna/article/view/30 0/239, (Diakses 09 Juli 2020), 91.

Muhaimin, Nuansa Baru Pendidikan Islam; Mengurai Benang Kusut Penddikan Islam, (Jakarta: PT. Raja Grafindo Persada, 2006), 84

Ni Luh Suyantini, Penerapan Model Pembelajaran Quantum Teaching untuk Meningkatkan Hasil Belajar IPA Siswa Kelas IXE Semester Ganjil SMP Negeri 2 Kubu Tahun Pelajaran 2017/2018, Jurnal IKA Vol. 17, No. 1 Maret 2019, https:// ejournal.undiksha.ac.id/index.php/IKA/article/view/198 40/12652, (Diakses 10 Juli 2020), 77.

Alfian Erwinsyah, Manajemen Kelas dalam Meningkatkan Efektifitas Proses Belajar Mengajar, Tadbir: Jurnal Manajemen Pendidikan Islam Volume 5, Nomor 2: Agustus 2017, http://journal.iaingorontalo.ac.id/index.php/tjmpi/article/view/ 392, (Diakses 10 Juli 2020) 98.

Didin Hafidhuddin, Hendri Tanjung, Shariah Principles on Management in Practice, (Jakarta: Gema Insani Press, 2006), 87

E. Mulyasa, Pedoman Manajemen Berbasis Madrasah, (Proyek Pemberdayaan Kelembagaan dan Ketatalaksanaan Pada Madrasah dan PAI pada Sekolah Umum Tingkat Dasar: 2004), 27

Laksamana Arnanda Harahap, Kompetensi Guru Pendidikan Agama Islam dalam Mengelola Kelas dan Mengatasi Kesulitan Belajar Peserta Didik di SMA Negeri Se-Kota Pekanbaru, Tesis, Pascasarjana Universitas Islam Negeri Sultan Syarif Kasim Riau 1441/2020, http:/ / repository.uinsuska.ac.id/29640/1/TESIS\%20LAKSAMAN\%20ARNANDA\%20H ARAHAP.pdf, (Diakses 11 Juli 2020), 40.

Wibowo, Manajemen Perubahan, (Jakarta: RajaGranfindo Persada, 2013). Hal.116

Surat Edaran Menteri Pendidikan dan Kebudayaan Nomor 4 Tahun 2020 tentang Pelaksanaan Kebijakan Pendidikan dalam Masa Darurat Penyebaran Corona Virus Disease (COVID-19), https:/ / pusdiklat.kemdikbud.go.id/ surat-edaran-mendikbud-no4-tahun-2020-tentang-pelaksanaan-kebijakan-pendidikan-dalammasa-darurat-penyebaran-corona-virus-disease-covid-1-9/, (Diakses 11 Juli 2020). 
Risnayanti, Implementasi Pendidikan Agama Islam Di Taman KanakKanak Islam Ralia Jaya Villa Dago Pamulang, (Jakarta: Perpustakaan Umum, 2004). 